\title{
Survey on Common Practices of Vegetables Cultivation in Floating Bed at Barishal District, Bangladesh
}

\author{
Md. Uzzal Hossain
}

Department of Botany, University of Barishal, Bangladesh

*(muhossain@bu.ac.bd)

This journal is licensed under a Creative Commons Attribution-Noncommercial 4.0 International License (CC-BY-NC). Articles can be read and shared for noncommercial purposes under the following conditions:

- BY: Attribution must be given to the original source (Attribution)

- NC: Works may not be used for commercial purposes (Noncommercial)

This license lets others remix, tweak, and build upon your work non-commercially, and although their new works must also acknowledge you and be non-commercial, they don't have to license their derivative works on the same terms.

License Deed Link: http://creativecommons.org/licenses/by-nc/4.0/

Legal Code Link: $h$ ttp://creativecommons.org/licenses/by-nc/4.0/legalcode

$A B C$ Research Alert uses the CC BY-NC to protect the author's work from misuse.

\section{Abstract}

Floating bed vegetable cultivation is now extended to wetland areas and long term water logging areas from southern parts of Bangladesh. Vegetables and other horticultural crops are now being cultivated in this method and getting popularity day by day. This method of cultivation is now providing numerous socio-economic, ecological and agricultural benefits towards climate change to local people. To face the circumstances from changed climate system effective adaptation actions and knowledge transfer is needed. This survey was conducted to find out socio-economic aspects, floral diversity cultivated, yield performance of cultivated crops, diversification of this technology, and also to find out the problems related to cultivation of this system. It was found that both sexes participate almost equally that leads to gender equity. In addition, a diversification in construction materials, fertilizers uses, yield purposes and crops cultivated were also found.

\section{Keywords}

Cultivation practices, Vegetable, Floating bed, Barishal

\section{INTRODUCTION}

Bangladesh is the most vulnerable country experiencing bad consequences of climate change (Hoque et al., 2015; Harmeling et al., 2014; UNDP, 2007) specially shrinking the arable land, due to its geographic location, high population density, low level of awareness, infrastructure and higher reliance on climate-sensitive natural resource based production such as agriculture, aquaculture (Denissen et al., 2012; Rahman et al., 2014; CCC, 2006). The country annually and inter-annually experience floods, cyclones, droughts, river bank erosions, salinity intrusions, tornados and other natural calamities that have adverse effect on agriculture, fishery, infrastructure, water and health (ADPC \& BCAS, 2008; Sutradhar et al., 2015). The southern, southwestern and the coastal areas of Bangladesh remain inundated for long periods every year, especially during the monsoon season. People in these areas have been coping with submerged/flooded conditions for generations (APEIS \& RIPSO, 2004). Barishal is under AEZ-13 named Ganges tidal floodplain and one of the riverine southern districts of Bangladesh 
laying between $22^{\circ} 27^{\prime}$ and $22^{\circ} 52^{\prime} \mathrm{N}$ and $90^{\circ} 01^{\prime}$ and $90^{\circ} 43^{\prime} \mathrm{E}$. The greater part of this region has smooth relief having large areas of salinity (FAO, 1997).

Floating agriculture is not a new practice in Bangladesh (Hoque et al. 2016); rather it is a wellestablished mode of conventional agriculture after receiving training and technical supports. According to their needs, people in different parts of Bangladesh have adopted, modified and named this practice differently (Islam and Atkins, 2007; Irfanullah et al. 2007, Islam et al., 2015), such as baira, boor, dhap, gathua, gatoni, geto, kandi and vasoman chash and floating agriculture; all these names represent this same traditional cultivation practice that can be scientifically referred to as hydroponics. In the past only Eichhornia crassipes species were used to make a floating bed, but today different aquatic macrophytes are used to build this due to lack of Eichhornia crassipes species at the time of bed preparation. The basic construction material of floating bed that supply nutrient to vegetables cultivated are aquatic weeds such as Eichhornia crassipes, Pistia stratoites, Najas graminea, Salvinia spp., Potamogeton alpinus, Bluxa japonica and Hygroryza aristata etc. (Irfanullah et al., 2011). Areas covered by the weed are cleared, with the beneficial effects of reducing breeding grounds for mosquitoes by harvesting water hyacinth (Saha, 2010). Furthermore, it is one of the popular modes of so called organic farming because once only organic fertilizers were used to yield increasing purposes. But due to competition and to meet up the demand artificial fertilizers are now being used in very few amount. Besides this, hybrid varieties along with local varieties are now being cultivated.

By cultivating crops in water, it is also possible to simultaneously harvest fish populations which reside in the beds (APEIS \& RIPSO, 2004). Nutrients (mainly N, P and K) result from decomposed bed materials are used by seedlings. However, cultivated vegetables seedlings can't uptake $100 \%$ of the total nutrient released. Furthermore, now it is alarming that farmers are applying artificial fertilizers to rich in competitive market. A part of these goes into aquatic ecosystem. Fishes, aquatic macrophytes and others microscopic aquatic flora and fauna uptake nutrients from the remaining part entered in aquatic ecosystem. As a result, it is also important for fish/hatchery cultivation in Bangladesh. However a certain part of nutrient entered into aquatic ecosystem pollutes water and sometimes settle down into the base. These settle down of nutrient result the decreasing of deepness of water bodies with rich nutrient called eutrophication. As a result of this water holding capacity of wetlands will be decreased day by day resulting another dimension of causes of flooding of surrounding low land areas.

To alleviation of poverty the practice of floating agriculture also helps supplement to the income of local communities (Saha, 2010). For poor and landless people it also provides greater food security by increasing the land output and supporting capacity (Irfanullah et al. 2007). People of practicing floatingbed cultivation are enjoying a better life economically, than those in other flood-affected areas who have not yet adopted this practice (Saha, 2010). It also has the capacity to provide employment opportunities within communities because the system is fairly labor intensive, (Haq et al., 2004). As both men and women can participate in the floating agriculture practices, it leads to improvements in gender equity. Considering the above factors, Alam and Chowdhury (2018); Hasan et al., (2017) and Hoque et al., (2016) carried out different survey towards farmers view on floating bed vegetables cultivation at Kaptai lake area (Rangamati), Wazirpur (Barishal) and Nazirpur (Pirojpur) respectively. In the present survey area, partial assessment related to this may be carried out. But present study was carried out at different villages in which no study was carried and with the following particular objectives: To assess the status of floating agricultural practices in the study area; to measure the demographic ratio and socio-economic aspects; to assess the respondents with regards to harvesting times $\&$ frequency, yield performance, problems faced.

\section{METHODOLOGY}

\section{1. Study area}

The survey was conducted at 10 villages of Banaripara upzilla in Barishal district during the cultivation time (wet season) where cultivation has been performed for many years and has a socio-economic impact on their livelihood. 


\section{2. Floating bed preparation and cultivation}

For making floating bed locally available aquatic weeds named Eichhornia crassipes (locally calle tagor/kochuripana), Hygroryza aristata (locally called fenna) are commonly used.

Farmers makes bottom part of bed with Eichhornia crassipes and top most layer with Salvinia molesta. During sowing of seeds of small size, farmers uses coconut dusts which stimulates decomposition of bed material and also prevent disturb from birds.

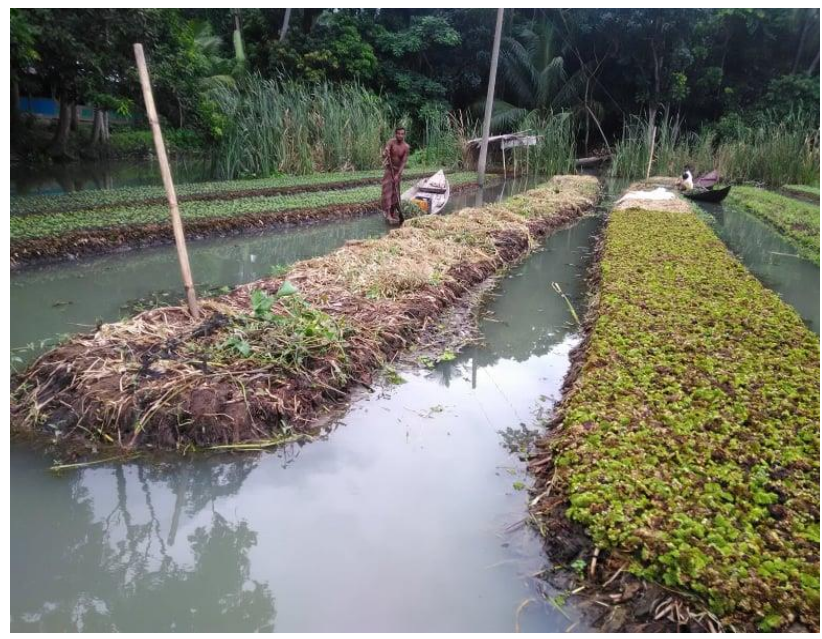

(a) Bed at initial stage of decomposition

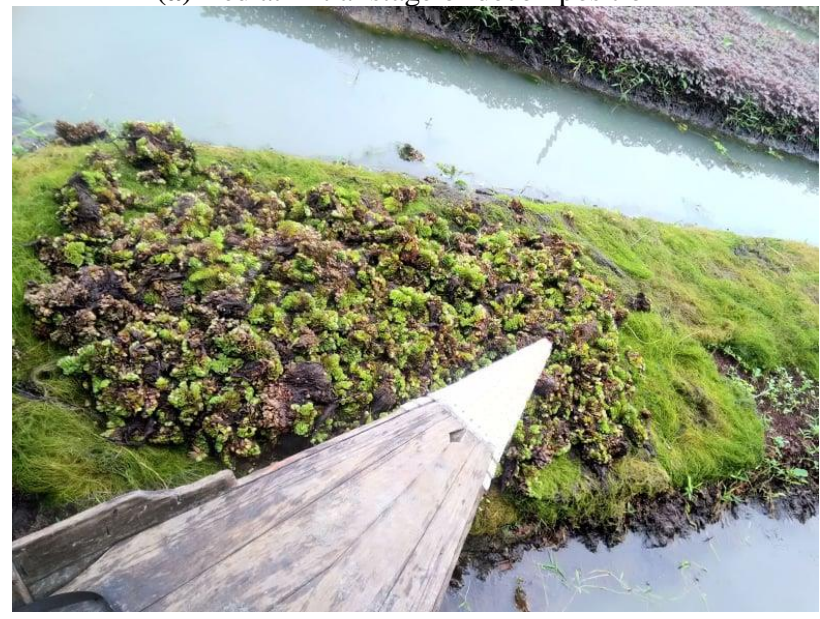

(c) Bed at final stage of decomposition

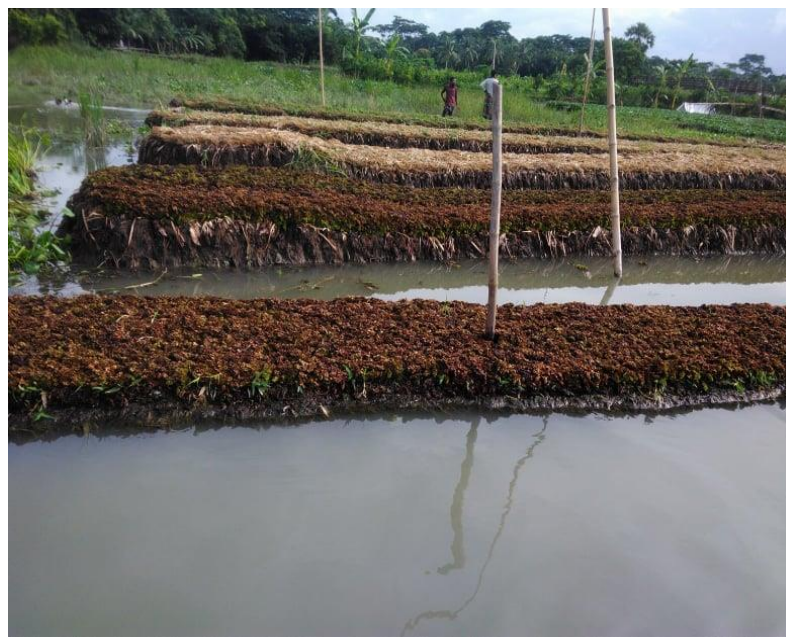

(b) Bed at medium stage of decomposition

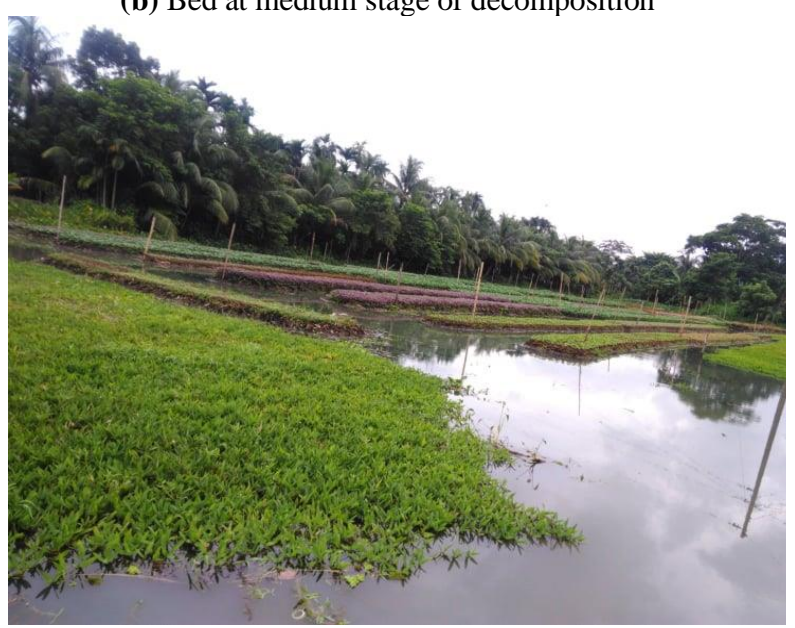

(d) Crops cultivated on beds

Figure 1: Floating beds at different stages of cultivation

\section{3. Data collection and analysis}

Interviews of 102 farmers who has been working for this cultivation were taken at the year 2019. Data related with required seed germination times, harvesting times were collected from farmers. While starting interview, the researcher took utmost care to make a relationship with the respondents, so that they feel free to share the information.

All possible precautions were taken to avoid bias and to maintain fidelity of responses. Suitable statistical analysis was done after data collection. 


\section{RESULT AND DISCUSSION}

\section{1. Demography and socio-economy of the informants}

Demographic information of informants was depicted in Table 1. It was seen that people from both of the sex contributed equally in this cultivation system, whereas male contributed more than female in today's land farming. In addition, people from age old contributed more than young. Occupation of the respondents are presented in Figure 2. About $62 \%$ of the respondents were found engaged in agricultural activities (Farmers) in the study area, respondents are housewives (22\%). People engaged in business and service sectors are negligible (Figure- 2).

\begin{tabular}{|cccc|}
\hline Parameters & $\begin{array}{c}\text { Demographic } \\
\text { group }\end{array}$ & $\begin{array}{c}\text { Number of } \\
\text { respondents }\end{array}$ & $\begin{array}{c}\text { \% of respondent } \\
\text { (about) }\end{array}$ \\
Age & $18-30$ & 12 & 12 \\
& $31-45$ & 37 & 36 \\
Gender & $46-60^{+}$ & 53 & 52 \\
& Female & 61 & 59 \\
& Male & 41 & 41 \\
\hline
\end{tabular}

Table 1: Demographic profile of the informants included during survey

Half of the year of the survey area remains inundated with water as a result there is no alternative scope of cultivation. As a result, farmers move towards to floating bed vegetable cultivation and the cultivation area is increasing day by day due to increase awareness. In addition, besides cultivating different vegetables and spices farmers can cultivate guava, banana, sugarcane, hog palm, papaya, coconut, betel nut, others fruit and different types of field crops between the space of two beds. Furthermore, our female correspond can also participate into this cultivation system and ultimately play vital role in family income sources.

\section{2. Types of crops grown}

Different types of crops that include both vegetables and spices are grown on floating bed as a single or mixed cropping. During survey it was recorded that raising seedling for selling purposes is more beneficial than harvesting yield purposes. But seedlings of all crops can't be sold to the local markets. The lists of cultivated vegetables for both raising seedling for selling and harvesting yield are showed in Table 2.

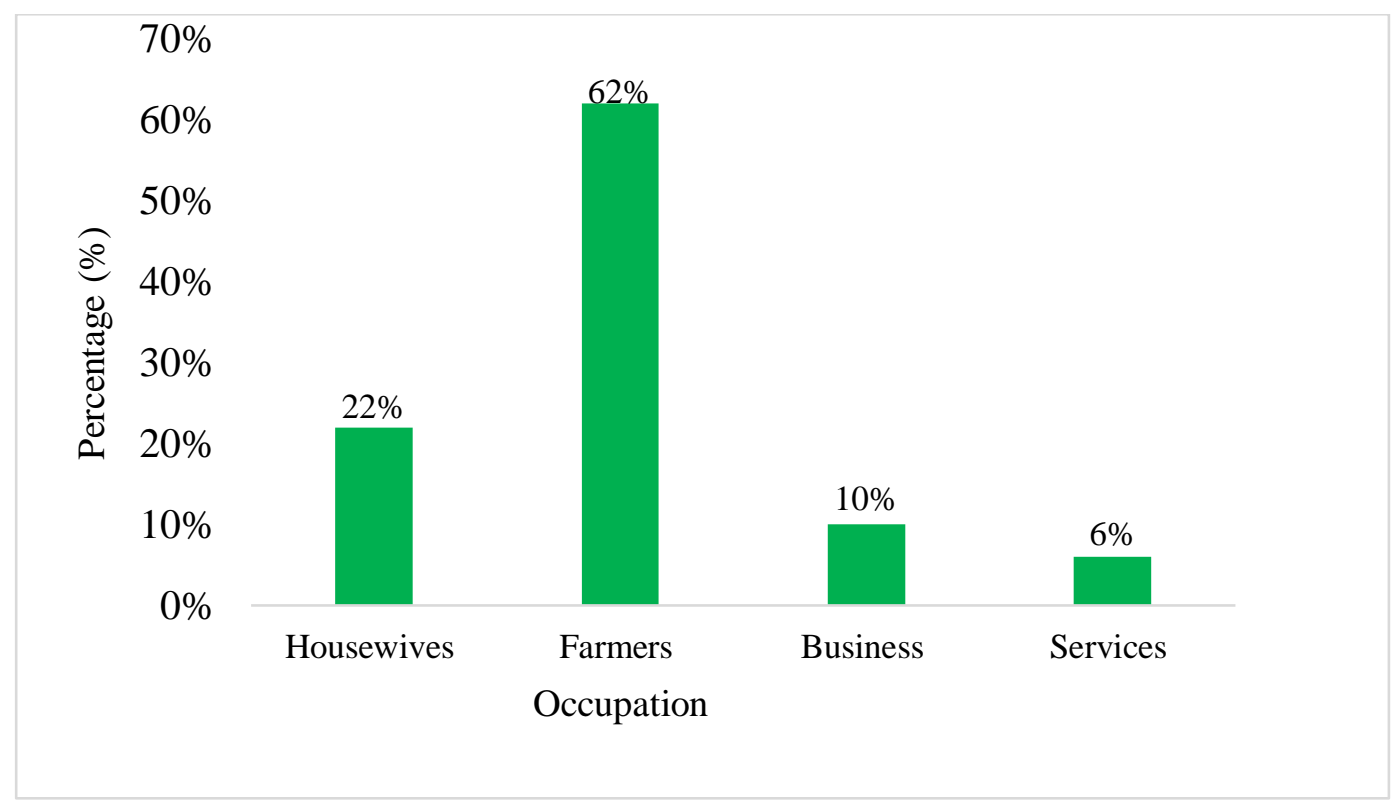

Figure 2: Percentage of respondent's occupation 


\begin{tabular}{|c|c|c|c|c|}
\hline Name & Scientific name & Crops Family & $\begin{array}{l}\text { Single } \\
\text { crops }\end{array}$ & $\begin{array}{l}\text { Mixed } \\
\text { crops }\end{array}$ \\
\hline Ladies finger & Abelmoschus esculentus (L) Moench. & Malvaceae & + & + \\
\hline Spinach & Spinacia oleraceae L. & Amaranthaceae & - & + \\
\hline Indian spinach & Basella alba L. & Basellaceae & - & + \\
\hline Red spinach & Amaranthus sp L. & Amaranthaceae & + & + \\
\hline Tomato & Lycopersicon esculentum Mill. & Solanaceae & + & + \\
\hline Taro & Colocasia esculenta (L.) Scott. & Araceae & - & + \\
\hline Cucumber & Cucumis sativus $\mathbf{L}$. & Cucurbitaceae & - & + \\
\hline Pumpkin & Cucurbita moschata Poir. & Cucurbitaceae & + & + \\
\hline Bottle gourd & Lagenaria siceraria (Mol) Standl. & Cucurbitaceae & - & + \\
\hline Bitter gourd & Momordica charantia $\mathbf{L}$. & Cucurbitaceae & - & + \\
\hline Ribbed gourd & Luffa acutangula Roxb. & Cucurbitaceae & - & + \\
\hline Cabbage & Brassica oleracea var. capitate $L$. & Brassicaceae & - & + \\
\hline Eggplant & Solanum melongena $L$. & Solanaceae & - & + \\
\hline Coriander & Coriandrum sativum $\mathbf{L}$. & Apiaceae & + & + \\
\hline Carrot & Daucus carota $\mathbf{L}$. & Apiaceae & + & + \\
\hline Chili & Capsicum аппиит $\mathbf{L}$. & Solanaceae & - & + \\
\hline Turmeric & Curcuma longa $\mathbf{L i n}$. & Zingiberaceae & + & + \\
\hline Bean & Lablab purpureus (L.) Sweet & Fabaceae & + & + \\
\hline
\end{tabular}

*+ indicates positive response to status;

*- indicates negative response to status

Table 2: List of vegetables and spices that cultivated in floating bed cultivation

\section{3. Intercultural operation}

The informants practiced various types of intercultural operation from seedling stage to harvesting time to different extents and when necessary. The list intercultural operations adopted by the respondents are shown in Table 3.

\begin{tabular}{|ccc|}
\hline Operation & Frequency & \% Respondent \\
& & \\
Weeding & $2-3$ & 100 \\
Irrigation & $1-2$ & 74 \\
Control of diseases & $1-2$ & 65 \\
Control of insects & $2-3$ & 70 \\
Repairing & $2-3$ & 80 \\
\hline
\end{tabular}

Table 3: Intercultural operations that are required

\section{4. Harvesting time}

\begin{tabular}{|c|c|c|c|}
\hline Crops & $\begin{array}{l}\text { Harvesting } \\
\text { time (DAC) }\end{array}$ & Frequencies & $\begin{array}{c}\text { Yields } \\
\text { (ton/ha) }\end{array}$ \\
\hline Ladies finger & $45-65$ & Two times/ week & $14-18$ \\
\hline Indian spinach & $42-55$ & 1-2 times/ week & $18-20$ \\
\hline Red spinach & $22-35$ & 1-2 times/week & $08-10$ \\
\hline Tomato & $50-70$ & 1-2 times/ week & $35-40$ \\
\hline Taro & $65-85$ & 1-2 times/ week & $08-12$ \\
\hline Cucumber & $45-60$ & 1 time/ week & $08-10$ \\
\hline Pumpkin & $80-90$ & 1 time/ week & $27-32$ \\
\hline Bottle gourd & $95-100$ & 1-2 times/ week & $15-18$ \\
\hline Bitter gourd & $65-70$ & 1-2 times/ week & $18-20$ \\
\hline Ribbed gourd & $60-65$ & 1time/ week & $12-14$ \\
\hline Cabbage & $70-75$ & 1-2 times/ week & $55-65$ \\
\hline Eggplant & $65-60$ & 1-2 times/ week & $58-65$ \\
\hline Coriander & $30-40$ & 2-3 times/ week & $05-07$ \\
\hline Chili & $70-80$ & 1-2 times/ week & $02-03$ \\
\hline Turmeric & $160-180$ & 1 time & $25-30$ \\
\hline Bean & $50-55$ & 1-2 times/ week & $08-12$ \\
\hline Carrot & $55-65$ & 1-2 times/ week & $20-25$ \\
\hline Kalmi shak & $20-25$ & 1-2 times/ week & $15-20$ \\
\hline Spinach & $20-25$ & $1-2$ week & $10-12$ \\
\hline
\end{tabular}

Table 4: Time, harvesting frequency and yield of produced vegetables in the study area. 
The time and frequency of harvesting of crops depends on factors named life span, habit and decomposition status of bed construction materials. However the time and frequency of harvesting of some frequently cultivated crops are represented in Table 4.

\section{5. Durability of floating beds}

It is beneficiary to the farmers if they can use the floating beds 7-8 months. Most of the floating beds (68\%) sustain 4-6 months; only $26 \%$ beds sustain $6-8$ months to use (Figure 3 ). The materials which are used to make the floating beds determine sustainability of a floating bed.

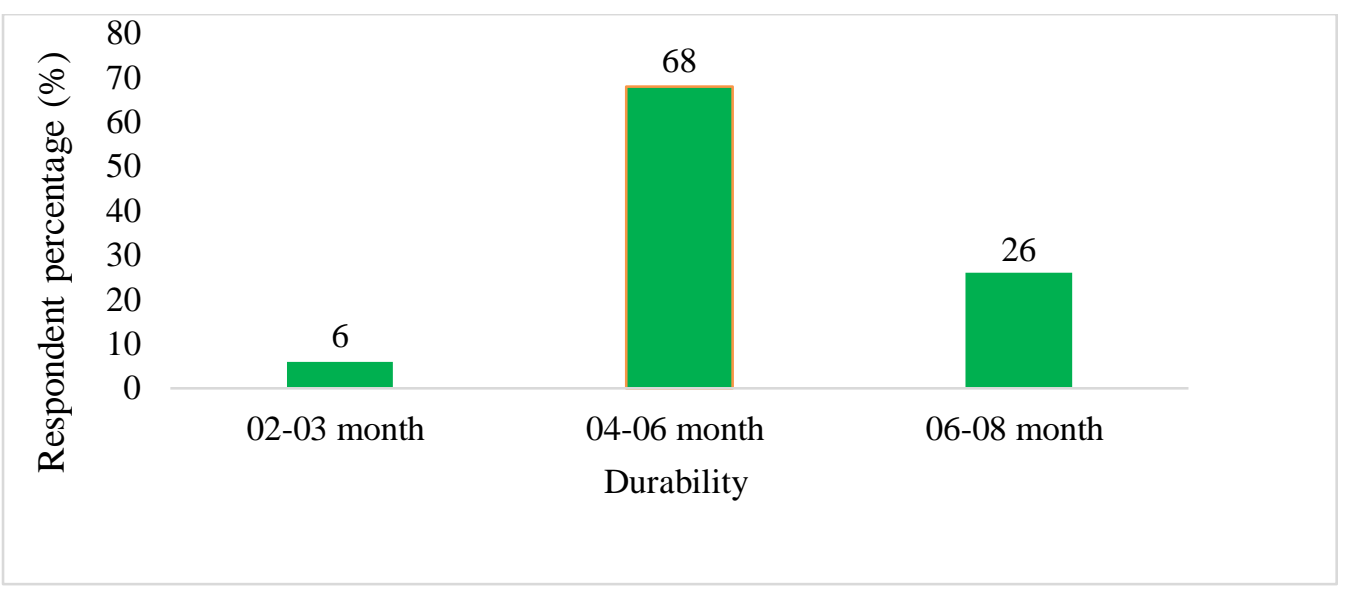

Figure 3: Percentage of respondents to durability

\section{6. Cost of making a floating bed}

In the study area the labor cost is not fixed, the range of labor cost to build a floating bed it varies from 200-400 taka. Once the female labor cost was low but nowadays it almost equal due to continuous increase of this cultivation and lack of male labor. Nearly $76 \%$ respondents that to build an average size floating bed it needs 350-500 taka. About 16\% respondents answered that they need 250-350 taka to build a floating bed as a labor cost (Figure 4). Almost 8\% people told they need 500-600 taka as labor cost. Very few family are interested to collect aquatic macrophytes to construct bed only for selling purposes. As a result farmers sometimes get readymade floating bed with comparatively high cost than homemade. Some families conserve aquatic macrophytes in their fallow land during monsoon season for selling purposes. This is one of the economic aspects of aquatic weeds.

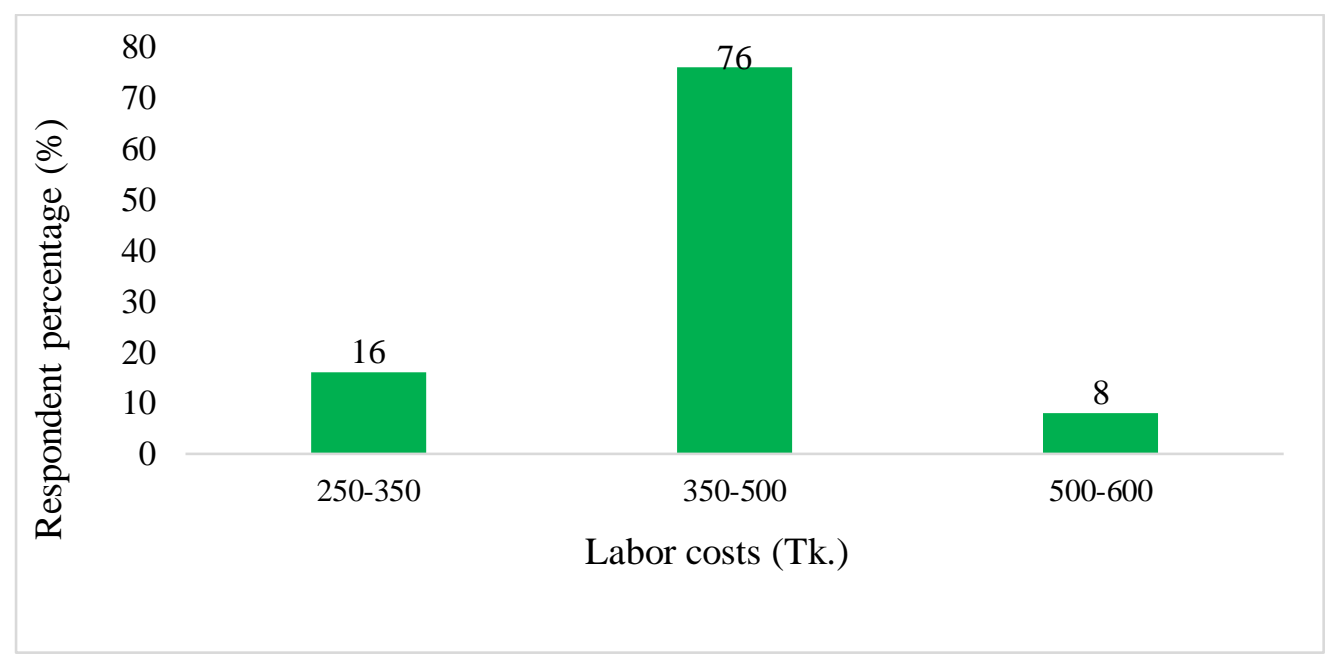

Figure 4: Percentage of respondents to labor cost 
Total cost to make a floating bed varies village to village and time to time. However, Where the water hyacinths are available, labor cost and other material cost is low there need less amount to make a bed of standard size. Some $72 \%$ respondents told they need 600-800 taka to build a complete floating bed. However, $20 \%$ of the respondents answered they need 800-1000 taka to build a bed. Some (8\%) of them told they need 1000-1200 taka to build a complete floating bed (Figure 5).

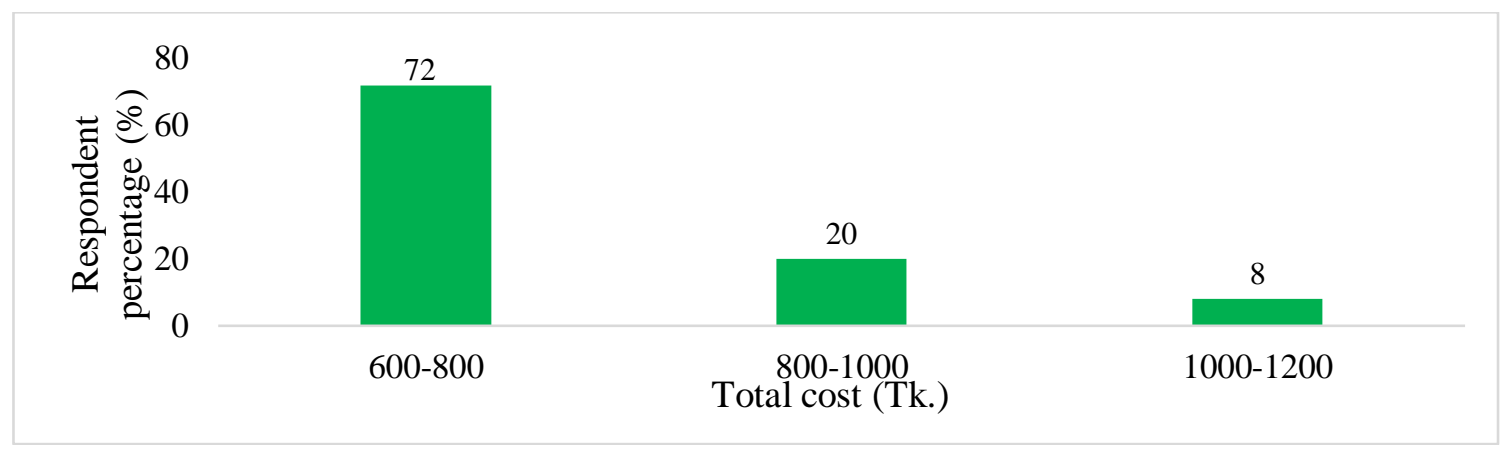

Figure 5: Percentage of respondents to total cost

\section{7. Problems to practice this cultivating system}

There are some problems to practice the system of floating bed in this study area. These are machinerun boats $(26 \%)$ and lack of labor at optimum time (22\%), lack of training (20\%), lack of proper capital $(19 \%)$ and middle man dealers (13\%) system. Machinery boats are very common in this area. As it is a large area people generally use these types of boats for their transportation (Figure-6). Due to less benefit in yield production than retailers because of middle man dealer, farmers intend to sell seedlings of different crops at yearly stages. As a result of this same bed can be used more than one time at same year.

\section{CONCLUSION}

Sea level rises due to global warming will under logged so more areas of Bangladesh and more land will become unavailable for crop production (BARC, 1991). The findings of the present survey conclude that farmers' idea about climate change are more or less appropriate and they are aware of climate change and floating agriculture is identified as sustainable and a profitable practice. For extension of this practices in other areas of Bangladesh it is recommended that necessary steps need to be taken by GOs and NGOs to provide financial help and training facilities that will motivate farmers towards this cultivation technology.

\section{ACKNOWLEDGEMENTS}

Author would like to express his sincere gratitude to respondents who shared their experience, knowledge and problems from the survey area. Author also would like to express to his sincere thanks to Ministry of Science and technology, Governments of the people republic of Bangladesh for financial help to perform a project in another titled. Author also grateful to Department of Botany, University of Barishal for al kind of technical and legislative helps.

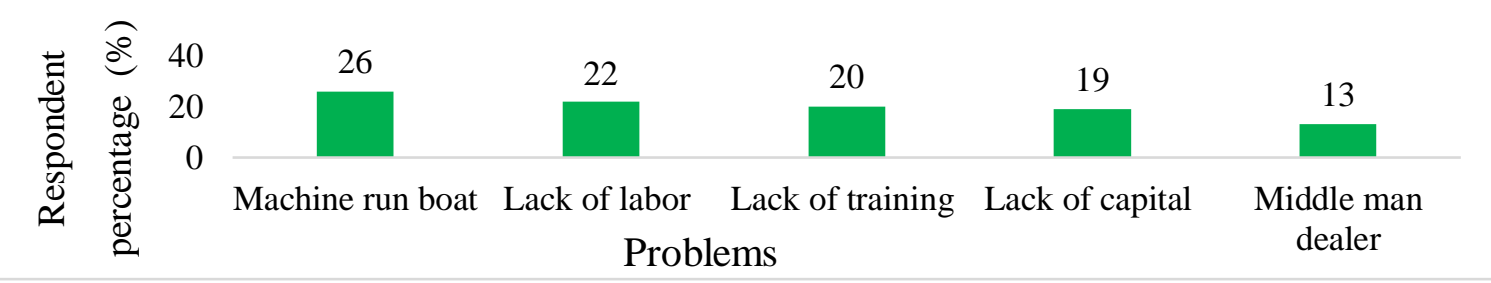

Figure 6: Percentage of respondents to problems faced. 


\section{REFERENCES}

ADPC \& BCAS (Asian Disaster Preparedness Centre and Bangladesh Centre for Advance Studies). 2008. "Draft Disaster Management Information Link Report." Ministry of Food and Disaster Management, Government of Peoples Republic of Bangladesh, Dhaka, Bangladesh.

Alam,K. and Chowdhury, M. A. T. 2018. Floating Vegetable Gardening (FVG) as a Sustainable Agricultural System in Bangladesh: Prospects for Kaptai Lake, Rangamati, Chittagong Hill-Tracts. OIDA International Journal of Sustainable Development 11:03. 43-58.

APEIS and RIPSO. 2004. Floating Agriculture in the flood-pr one or submerged areas in Bangladesh (Southern regions of Bangladesh). Bangladesh: APEIS and RIPSO.

BARC. 1991. Agro-ecological database, BARC Computer Centre. Bangladesh Agricultural Research Council: Dhaka. CCC (Climate Change Cell). 2006. Climate Variability and Change in Bangladesh: Impacts, Vulnerability and Risks.

Denissen, A. K. 2012. Climate Change \& its Impacts on Bangladesh.

FAO (1997). Land resources appraisal of Bangladesh for agricultural development, report 2: Agro-ecological regions of Bangladesh. UNDP, FAO. 570 pp.

Hasan, S.S., Mohammad, A., Ghosh, M. K. and Khalil, M. I. 2017. Assessing of Farmers' Opinion towards Floating Agriculture as a Means of Cleaner Production: A Case of Barisal District, Bangladesh. British Journal of Applied Science \& Technology 20(6): 1-14.

Harmeling, S. and Eckstein, D. 2014. Global Climate Risk Index.

Haq, A. H. M. R., Ghosal, T. K.and Ghosh, P. 2004. Cultivating Wetlands in Bangladesh. India: LEISA, ILEIA, The Netherlands, Vol: 20 No. 04 pp: 18-20

Hoque, M. Z. 2015. Climate Change Awareness and Risk Perception by the Coastal People of Bangladesh. International journal of multidisciplinary research and development. 2(8): 431-440.

Hoque, M. Z., Haque, M. E., Afrad, M. S. and Islam. M. N. 2016. Effectiveness of Floating Agriculture for Adapting Climate Change in Southern Bangladesh. International Journal of Economic Theory and Application 2016; 3(1): $14-25$

Irfanullah, H. M., Adrika, A., Ghani, A. and. Khan, Z. A. 2007. Introduction of Floating Gardening in the North - eastern Wetlands of Bangladesh for Nutritional Security and Sustainable Livelihood. Renewable Agriculture and Food Systems 23(2):89-96.

Irfanullah, H. M., Azad, M. A. K., Kamruzzaman, M. and Wahed, M. A. 2011. Floating gardening in Bangladesh: a means to rebuild life after devastating flood. Indian Journal of Traditional Knowledge. 10(1):31-38.

Islam M. A., Kamruzzaman, M., Akter, A. and Roy, P. C. 2015. Perception of haor farmers about the innovative features of floating farming. International Journal of Natural and Social Sciences, 2(4): 52-58.

Islam, T. and Atkins, P. 2007. Indigenous Floating Cultivation: A Sustainable Agricultural Practice in the Wetlands of Bangladesh. Development in Practice 4(1):130-136

Rahman, M. 2014. Framing Ecosystem-based Adaptation to Climate Change: Applicability in the Coast of Bangladesh, Dhaka, Bangladesh: IUCN, 43pp.

Saha, S. K. 2010. Soilless Cultivation for Landless People: An Alternative Livelihood Practice through Indigenous Hydroponic Agriculture in Flood-prone Bangladesh. Ritsumeikan Asia Pacific University.139-152pp.

Sutradhar, L. C., Bala, S. K., Islam, A. K. M. S., Hasan, M. A Paul, S., Rahman, M. M., Pavel, M. A. A. and Billah, M. 2015. A Review of Good Adaptation Practices on Climate Change in Bangladesh. International Conference on Water\& Flood Management (ICWFM-2015). PP: 607-614.

UNDP (United National Development Programme). 2007. Country-in-focus: Bangladesh. 